\title{
Physiological, biochemical and productive changes in sesame genotypes subjected to different rates of water replenishment
}

\author{
Maria S. R. Lima ${ }^{1}$, Maria do S. Rocha ${ }^{2}$, Alberto S. de Melo² \& Wellison F. Dutra ${ }^{1}$ \\ ${ }^{1}$ Universidade Federal da Paraíba/Programa de Pós-Graduação em Agronomia. Areia, PB. E-mail: mariasuelirocha@hotmail.com - ORCID: 0000-0001- \\ 5248-8122; wellison_eu@hotmail.com - ORCID: 0000-0002-0378-8046 \\ ${ }^{2}$ Universidade Estadual da Paraíba/Núcleo de Pesquisa em Agrárias. Campina Grande, PB. E-mail: marialirium@hotmail.com (Corresponding author) \\ - ORCID: 0000-0002-1240-5772; alberto@eupb.edu.br - ORCID: 0000-0001-9902-8078
}

\section{Key words:}

Sesamum indicum L.

evapotranspiration

antioxidant enzymes

\begin{abstract}
A B S T R A C T
The sesame crop has stood out due to the high nutritional content of its seeds, in addition to being able to be cultivated in the tropical and subtropical regions such as Northeast Brazil. Thus, it is necessary to identify the physiological, biochemical and productive changes related to the tolerance to stress. Objective of this study was to evaluate the physiological, biochemical and productive aspects of sesame genotypes as a function of different rates of water replenishment. The experiment was carried out at the Embrapa Cotton Experimental Unit, located in the municipality of Barbalha-CE, Brazil, under field conditions. The experiment was carried out in a randomized complete block design, with treatments in a factorial scheme $(4 \times 6)$, corresponding to four irrigation depths $(40,70,100$ and $130 \%$ ETo) and six sesame genotypes (G1 = T3-EGSGO3; G2 = T7-EGSGO7; G3 = T5-EGSGO5; G4 = T2-EGSGO2; G5 = T6-EGSGO6; G6 = T4-EGSG04), with three replicates. Data corresponding to the following variables were collected: leaf area, photosynthetic pigments, relative water content in leaf, electrolyte leakage, catalase, peroxidase, yield and oil content. The genotypes did not differ statistically and there were differences in the variables between the water replacement rates. Increments in growth and, consequently, in production, enzymatic activity, oil content and maximum production potential were observed with water depths between 75 and 90\% ETo. Contents of chlorophyll a and b, total chlorophyll and carotenoids, were increased with the application of $80 \%$ ETo.
\end{abstract}

\section{Palavras-chave:} Sesamum indicum L. evapotranspiração enzimas antioxidantes

\section{Alterações fisiológicas, bioquímicas e produtiva em genótipos de gergelim submetidos a diferentes taxas de reposição hídrica}

\section{R E S U M O}

O cultivo de gergelim vem se destacando devido ao alto teor nutricional de suas sementes, além de poder ser cultivado nas regiões tropicais e subtropicais como o Nordeste brasileiro, sendo necessária a identificação das alterações fisiológicas, bioquímicas e produtivas relacionadas com a tolerância ao estresse. Objetivou-se avaliar o comportamento fisiológico, bioquímico e produtivo de genótipos de gergelim em função de diferentes taxas de reposições hídricas. O experimento foi realizado na Unidade Experimental da Embrapa Algodão, localizada no Município de Barbalha, CE, sob condições de campo. O delineamento adotado foi em blocos casualizados, com tratamentos em esquema fatorial $(4 \times 6)$, correspondendo a quatro lâminas de irrigação $(40 ; 70 ; 100$ e $130 \%$ da ETo) e seis genótipos de gergelim $(\mathrm{Gl}=$ T3-EGSGO3; G2 = T7-EGSGO7; G3 = T5-EGSGO5; G4 = T2-EGSGO2; G5 = T6-EGSGO6; G6 = T4-EGSG04) com três repetições. Foram coletados dados correspondentes às variáveis: área foliar, pigmentos fotossintéticos, teor de relativo de água na folha, extravasamento de eletrólitos, catalase, peroxidase, produtividade e teor de óleo. Os genótipos de gergelim não diferiram estatisticamente, no entanto houve diferenças entre as reposições hídricas com um aumento no crescimento e consequentemente, na produção, atividade enzimática, teor de óleo e o potencial máximo da produção com a aplicação de lâminas entre 75 e $90 \%$ da ETo. O conteúdo de clorofila a e b, total e carotenoides foram incrementados com a aplicação de $80 \%$ da ETo. 


\section{INTRODUCTION}

In Northeast Brazil, where rainfall scarcity and/or poor distribution prevails, water deficit is a common and limiting condition to agricultural production, which makes the cultivation in the rainy period (rainfed) a highly vulnerable alternative. Nevertheless, in these regions, irrigation can be used to supplement rainfall, which leads to improvement in the growth, development and yield of crops. According to Bernardo et al. (2009), water replacement in the soil makes the production viable, regularizes and completes the use of soil, and can increase crop production. Additionally, these authors highlight that cultivation success depends on supplemental irrigation during the critical period of the crop.

Sesame (Sesamum indicum L.) is one of the first oilseed crops used by humans, occupying the ninth position among the most cultivated in the world (Bezerra et al., 2010; Perin et al., 2010; Mesquita et al., 2013; Pinto et al., 2014; Silva et al., 2014). Its yield depends on various climatic factors, such as temperatures between 25 and $30^{\circ} \mathrm{C}$, altitudes below $500 \mathrm{~m}$ and rainfall from 500 to $650 \mathrm{~mm}$ (Arriel et al., 2009). The sesame crop is resistant to drought and can produce with $300 \mathrm{~mm}$ of water well distributed along the cycle (Bernardo et al., 2009), which allows its cultivation in arid or semi-arid zones and in periods of scarce rainfall.

In the last years, many studies have been carried out using sesame, usually involving spacing, plant density and irrigation (Pinto et al., 2014). However, no studies were found on the determination of physiological and biochemical variables in genotypes of sesame under different water depths.

In this context, this study aimed to evaluate the physiological, biochemical and productive behavior of sesame genotypes as a function of different rates of water replacement.

\section{Material AND Methods}

The experiment was carried out from September to December 2013 at the Embrapa Cotton Experimental Unit, located in the municipality of Barbalha, CE, Brazil ( $7^{\circ} 19^{\prime} \mathrm{S} ; 39^{\circ}$ $\left.18^{\prime} \mathrm{W} ; 415.74 \mathrm{~m}\right)$. The climate of the region is Aw', according to Köppen's classification, characterized as rainy tropical, very hot, with rainfalls predominantly in the summer and winter. The region has mean rainfall of $1523 \mathrm{~mm}$, mean air temperature of $26.9{ }^{\circ} \mathrm{C}$ and relative humidity of $69 \%$ (Data provided by the Embrapa Cotton Meteorological Station). Along the experimental period, temperature, relative humidity, wind speed and rainfall data (Table 1) were collected at the Embrapa Cotton Meteorological Station, in Barbalha-CE.

The experiment was conducted in a clayey soil, sampled until $100 \mathrm{~cm}$ deep and classified as clay loam Fluvic Neosol (RY),

Table 1. Mean temperature (Tm), relative air humidity $(\mathrm{RH})$, wind speed (WS) and rainfall $(\mathrm{P})$ recorded along the experimental period

\begin{tabular}{lcccc}
\hline Month & $\begin{array}{c}\mathrm{Tm} \\
\mathbf{(} \mathbf{C})\end{array}$ & $\begin{array}{c}\text { RH } \\
\mathbf{( \% )}\end{array}$ & $\begin{array}{c}\text { WS } \\
\left(\mathbf{m ~ s}^{-1}\right)\end{array}$ & $\begin{array}{c}\text { P } \\
(\mathbf{m m})\end{array}$ \\
September & 37.83 & 67 & 2.38 & 0.76 \\
October & 37.94 & 66 & 2.62 & 4.82 \\
November & 38.45 & 63 & 2.62 & 3.80 \\
December & 38.88 & 63 & 2.66 & 3.81 \\
\hline
\end{tabular}

whose textural and physical characterizations were performed at the Irrigation and Salinity Laboratory of the Academic Unit of Agricultural Engineering of the Federal University of Campina Grande. For soil chemical characterization, according to the methodology of Carmo et al. (2000), before installing the experiments, samples were collected in the 0-0.20 m layer using a soil sampler, and taken to the Soil and Plant Nutrition Laboratory of the Embrapa Cotton, for analysis, and the following values were obtained: $\mathrm{pH}\left(\mathrm{H}_{2} \mathrm{O}\right)=6.8 ; \mathrm{P}=5.4 \mathrm{mg} \mathrm{dm}^{-3}$; $\mathrm{K}^{+}=0.14 \mathrm{cmol}_{\mathrm{c}} \mathrm{dm}^{-3} ; \mathrm{Na}^{+}=0.28 \mathrm{cmol}_{c} \mathrm{dm}^{-3} ; \mathrm{H}^{+}+\mathrm{AL}^{3+}=$ $0.33 \mathrm{cmol}_{\mathrm{c}} \mathrm{dm}^{-3} ; \mathrm{Al}^{3+}=$ Not detected; $\mathrm{Ca}^{\mathrm{c}+}=9.53 \mathrm{cmol} \mathrm{dm}_{\mathrm{c}}^{-3}$; $\mathrm{Mg}^{2+}=4.92 \mathrm{cmol}_{c} \mathrm{dm}^{-3}$; sum of cations $=14.87 \mathrm{cmol}_{\mathrm{c}} \mathrm{dm}^{-3}$ and organic matter $=12.3 \mathrm{~g} \mathrm{~kg}^{-1}$.

The experimental design was randomized complete blocks, with treatments in factorial scheme $(4 \times 6)$, corresponding to four irrigation depths (40; 70; 100 and $130 \% \mathrm{ETo})$ and six sesame genotypes (G1 = T3-EGSGO3; G2 = T7-EGSGO7; G3 = T5-EGSGO5; G4 = T2-EGSGO2; G5 = T6-EGSGO6; G6 = T4-EGSG04), totaling 24 treatments, with three replicates. The experimental plot comprised four rows, and the two central rows were used for evaluations.

Tillage in the experimental area consisted in one plowing and four cross harrowing procedures, using a leveling harrow. Then, basal fertilization was performed based on soil chemical analysis, using a dose equivalent to $300 \mathrm{~kg} \mathrm{ha}^{-1}$ of monoammonium phosphate - MAP ( $11 \% \mathrm{~N}$ and $\left.46 \% \mathrm{P}_{2} \mathrm{O}_{5}\right)$. Top-dressing fertilizations were performed after thinning or 45 days after emergence (DAE), applying 100 and $50 \mathrm{~kg} \mathrm{ha}^{-1}$ of urea $(45 \% \mathrm{~N})$ and potassium chloride $\left(60 \% \mathrm{~K}_{2} \mathrm{O}\right)$, respectively, in furrows opened parallel to the lateral rows.

Irrigation management was performed using the water depth principle, based on the replacement of reference evapotranspiration (ETo) for two consecutive days. ETo was estimated using the Penman-Monteith equation standardized by FAO (Pereira et al., 1997), and climate data were daily collected at the Embrapa Cotton Meteorological Station in Barbalha-CE. Irrigation depth $(\mathrm{Li})$ and irrigation time (Ti) were calculated according to Mantovani et al. (2006).

The sesame genotypes used were white and creamcolored, all developed by the Brazilian Agricultural Research Corporation (Embrapa Cotton). Their main characteristics include: cycle of 90-95 days, beginning of flowering at 35 days, mean yield of $1,000 \mathrm{~kg} \mathrm{ha}^{-1}$, oil content between 50 and $53 \%$ and resistance to the main diseases of the crop (Arriel, et al., 2009).

All evaluations, except of production, were carried out at 90 days after emergence (DAE). Total leaf area $\left(\mathrm{cm}^{2}\right)$ was determined by measuring the length and width of leaflets and using the equation proposed by Silva et al. (2002).

Leaf relative water content was measured according to Smart \& Bingham (1974). Cell membrane integrity evaluation, based on electrolyte leakage, was expressed as percentage of conductivity in relation to the total conductivity. Chlorophylls $a, b$ and total, and carotenoids were extracted using the solvent dimethyl sulfoxide (Hiscox \& Israelstam, 1979).

At 50 DAE, leaf samples were collected to determine enzymatic activity: catalase (CAT) according to Havir \& McHale (1987); and peroxidase (POD), based on peroxide consumption (Dann \& Deverall, 2000). 
At 95 DAE, harvest was done manually by cutting the whole plant at soil level. Then, plants were air-dried for seven days to facilitate the removal of seeds from the capsules. Yield was estimated based on the production obtained in the evaluation area of the experimental plot.

Oil content in the seeds was quantified by nuclear magnetic resonance (NMR), based on non-destructive tests, in which the value found results from the magnetic field scanning of the sample (Oxford Instruments, 2007).

Data of the response variables were subjected to the analysis of variance by $\mathrm{F}$ test (Fisher) at 0.05 probability level. Quantitative factors (irrigation depth) were subjected to polynomial regression analyses, selecting the model of highest significance in the F test (Ferreira, 2008). Analyses were carried out using the statistical programs Sisvar 5.3 and Table Curve 2D.

\section{Results AND Discussion}

Table 2 shows the analysis of variance summary for the growth physiological, biochemical and production variables. Irrigation depths influenced leaf area (LA), total leaf phytomass (TLP), chlorophyll $a$ (Chla), chlorophyll $b$ (Chlb), carotenoids (CAR), total chlorophyll (Chlt), catalase (CAT), peroxidase (POD), yield (Y), oil content (OC), electrolyte leakage (EL), relative water content (RWC), at 0.01 probability level. For the interaction irrigation depth $\mathrm{x}$ genotypes, there was no significance.

Sesame leaf area (LA) and total leaf phytomass (TLP) values fitted to a quadratic polynomial model (Figures $1 \mathrm{~A}$ and $1 \mathrm{~B}$ ). Maximum points of LA $\left(63.29 \mathrm{~cm}^{2}\right)$ and TLP $(7.62 \mathrm{~g})$ were estimated at water replacement rates equivalent to 85.75 and $86.07 \%$ ETo, respectively. Increased water replacement in the soil resulted in decreases of 48.81 and $56.34 \%$ in LA and TLP, concomitantly, reaching values statistically similar to those found with water replacement of $40 \%$ ETo (Figure 1A and 1B). This behavior demonstrates sesame sensitivity to both deficit and excess of water in the soil.

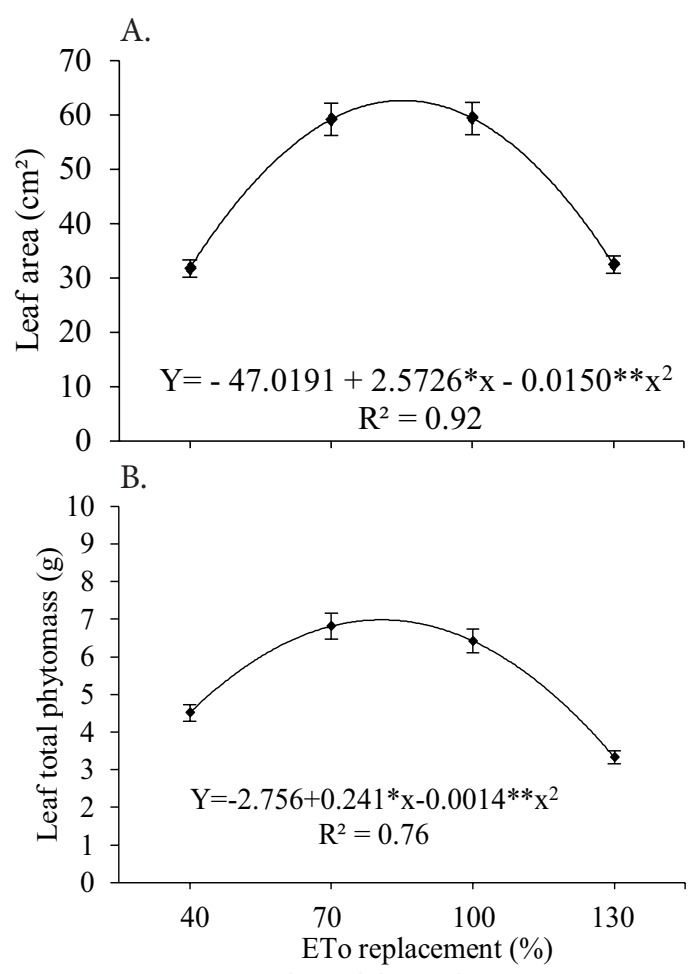

Figure 1. Leaf area (A) and total leaf phytomass (B) of sesame genotypes subjected to water replacement at 90 days after sowing

Similar response was found by Silva et al. (2002), who observed that leaf area at 90 DAE was drastically affected by irrigation depths lower than $250 \mathrm{~mm}$ and higher than $1000 \mathrm{~mm}$, and maximum leaf area was obtained with the application of $698.88 \mathrm{~mm}$. These results corroborate the hypothesis that sesame is sensitive to water stress.

Plant water relationships have been widely investigated under water deficit conditions, and leaf water content is accepted as an indicator of plant water conditions. In the sesame genotypes evaluated here, the maximum estimated relative water content (RWC) $(22.81 \%)$ was found with estimated water replacement of $52.16 \%$ ETo (Figure 2A), which represents an increment of $14.32 \%$ in comparison to the value found with water replacement of $40 \%$ ETo.

Table 2. Summary of analysis of variance for leaf area (LA), total leaf phytomass (TLP), chlorophyll a (Chla), chlorophyll b (Chlb), carotenoid (CAR), total chlorophyll (Chlt), catalase (CAT), peroxidase (POD), yield (Y), oil content (OC), electrolyte leakage (EL), relative water content (RWC), in sesame genotypes subjected to different rates of water replacement at 90 days after sowing

\begin{tabular}{|c|c|c|c|c|c|c|c|}
\hline \multirow{2}{*}{ SV } & \multirow{2}{*}{ DF } & \multicolumn{6}{|c|}{ Mean square } \\
\hline & & $\overline{L A}$ & TLP & Chla & Chlb & CAR & Chlt \\
\hline Block & 2 & $0.7379^{\text {ns }}$ & $5.418^{*}$ & $130782.32 * \star$ & $136.99^{\text {ns }}$ & $7473.16^{\star \star}$ & $1150.06^{\mathrm{ns}}$ \\
\hline Irrig. Depth (L) & 3 & 4804.7947 ** & $67.543^{\star *}$ & $365794.53^{\star \star}$ & $3082.73^{\star *}$ & $10221.40^{* *}$ & $142850.5^{\star \star}$ \\
\hline Linear & 1 & $4.3212^{\mathrm{ns}}$ & $4.534^{\mathrm{ns}}$ & $4810.74^{\text {ns }}$ & $16.17^{* \star}$ & $5150.13 n s$ & $82576.9 * *$ \\
\hline Quadratic & 1 & $13280.025^{\star \star}$ & $159.965^{\star *}$ & $753471.70^{\star * *}$ & $6002.17^{\star *}$ & $14314.25^{\star \star}$ & $205426.2^{\star *}$ \\
\hline Genotypes (G) & 5 & $112.1498^{\text {ns }}$ & $1.034^{\mathrm{ns}}$ & $9377.03^{\text {ns }}$ & $144.85^{\text {ns }}$ & $171.34^{\text {ns }}$ & $2705.31^{\text {ns }}$ \\
\hline Int. LXG & 15 & $22.5634^{\mathrm{ns}}$ & $5.339^{\text {ns }}$ & $6087.27^{\text {ns }}$ & $325.36^{\text {ns }}$ & $496.07^{\text {ns }}$ & $1410.36^{\text {ns }}$ \\
\hline Residual & 46 & 59.0974 & 1.4947 & 5845.59 & 202.90 & 1416.75 & 1764.7 \\
\hline CV (\%) & & 16.84 & 23.85 & 22.77 & 30.13 & 22.82 & 15.75 \\
\hline & & CAT & POD & $\bar{Y}$ & $\overline{O C}$ & $\overline{E L}$ & RWC \\
\hline Block & 2 & $18.07^{*}$ & $80.12 n s^{* *}$ & 85689.758* & $131.801^{\text {ns }}$ & $131.14^{*}$ & $231.53^{*}$ \\
\hline Irrig. Depth (L) & 3 & $117.25^{\star *}$ & $3781.36^{* *}$ & $578575.204^{* *}$ & $18969.6222^{* *}$ & $5012.06^{\star *}$ & $133.46^{*}$ \\
\hline Linear & 1 & $5.15^{\text {ns }}$ & $587.45^{\star \star}$ & $14357.775^{\text {ns }}$ & $7.140^{\text {ns }}$ & $515.34^{* *}$ & $248.56^{\text {ns }}$ \\
\hline Quadratic & 1 & $223.03^{* *}$ & $9637.53^{\text {ns }}$ & $727549.888^{* *}$ & $6046.365^{\text {** }}$ & $6134.68^{* *}$ & 30.22 ** \\
\hline Genotypes (G) & 5 & $12.77^{\text {ns }}$ & $350.91^{\text {ns }}$ & $12943.420^{\text {ns }}$ & $143.614^{\text {ns }}$ & $101.98^{*}$ & $22.40^{\text {ns }}$ \\
\hline Int. LXG & 15 & $3.71^{\text {ns }}$ & $185.67^{\text {ns }}$ & $11122.65^{\mathrm{ns}}$ & $160.711^{\mathrm{ns}}$ & $10.12^{\text {ns }}$ & $27.45^{\mathrm{ns}}$ \\
\hline Residual & 46 & $4.87^{*}$ & 244.94 & 23117.187 & 86.403 & 39.79 & 54.59 \\
\hline CV (\%) & & 30.42 & 33.92 & 35.68 & 20.87 & 15.49 & 11.52 \\
\hline
\end{tabular}

SV- Sources of variation; CV- Coefficient of variation; DF - Degrees of freedom; Int.- Interaction; **, Significant at 0.01 probability level; ns - not significant by F test ( $p<0.05)$ 
A.

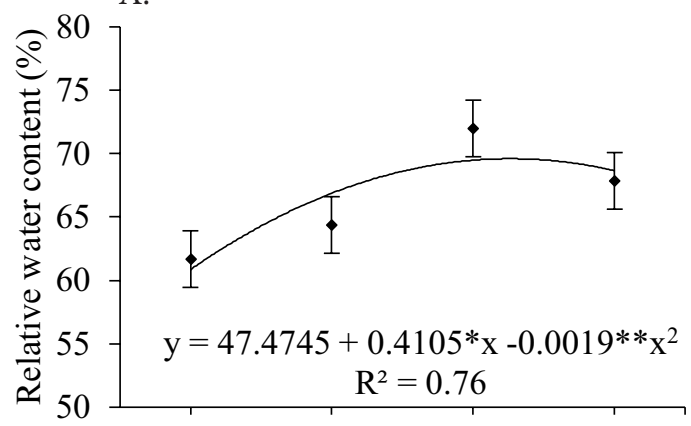

B.

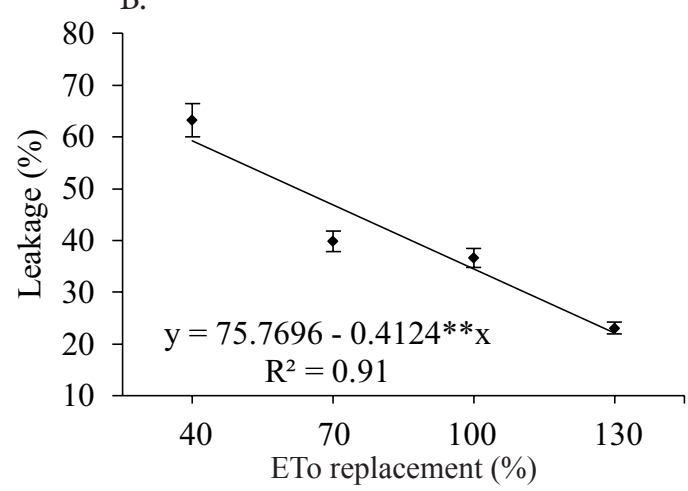

Figure 2. Relative water content (A) and electrolyte leakage (B) in sesame genotypes subjected to water replacement at 90 days after sowing

The reductions in RWC observed here were lower than those reported by Pinto et al. (2014), who obtained mean decrease of $27 \%$ by exposing sesame plants to successive cycles of water deficit. These results reinforce the hypothesis that continuous water availability, even in small amount ( $40 \%$ ETo), induces greater maintenance of water content in the leaves, which may influence the functioning of the photosynthetic apparatus.

The increase in electrolyte leakage as soil water content decreased can be attributed to a consequence of the limitation in photosynthesis imposed by the water deficit, which results in disruption of membrane integrity, triggered by the overproduction of reactive oxygen species (ROS). High contents of these compounds can reduce the activity of enzymes, cause peroxidation of lipids, oxidation of proteins and, in the most advanced stage, kill the cell (Sharma et al., 2012).

For electrolyte leakage (EL), the data of the sesame genotypes fitted to a decreasing linear model and maximum estimated value (59.27\%) was found with $40 \%$ ETo replacement (Figure 2B). It is worth noting that water replacement variation from 40 to $130 \%$ ETo resulted in reduction of $62.61 \%$ in the EL of the sesame genotypes.

Water deficit is closely related to the loss of pigments and, consequently, to the reduction in the photosynthetic and productive capacity of plants. Hence, analysis of photosynthetic pigments is essential to evaluate the health and integrity of internal cell apparatus during photosynthesis (Taiz \& Zeiger, 2009; Rigon et al., 2012), as well as an indicator of the damages suffered.

In the sesame plants evaluated, chlorophyll contents $(a, b$ and total) fitted to a quadratic polynomial model (Figure 3A, $\mathrm{B}$ and $\mathrm{C})$ and their maximum estimated values $(499.74,66.78$,
A.

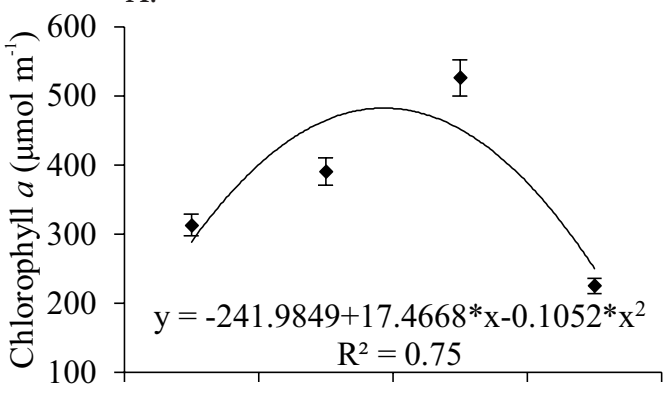

B.

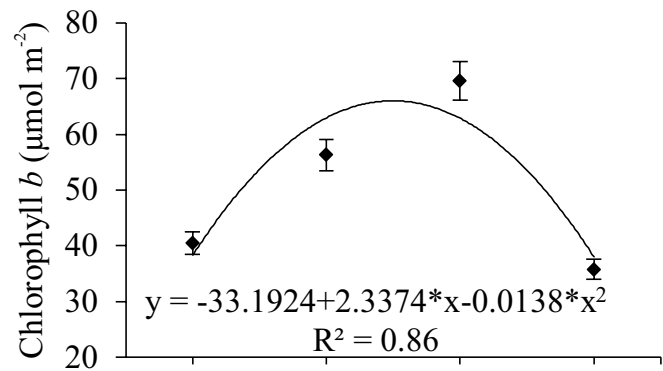

C.

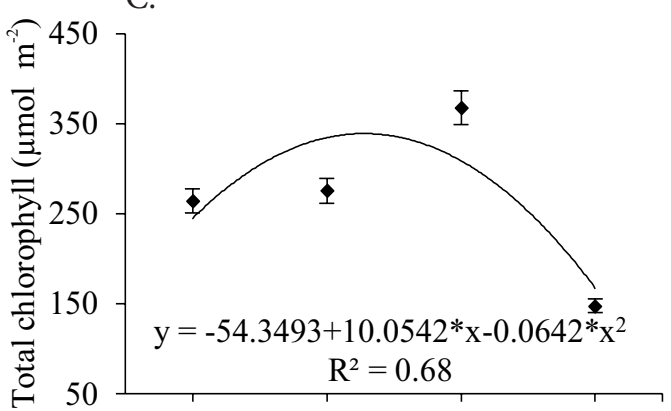

D.

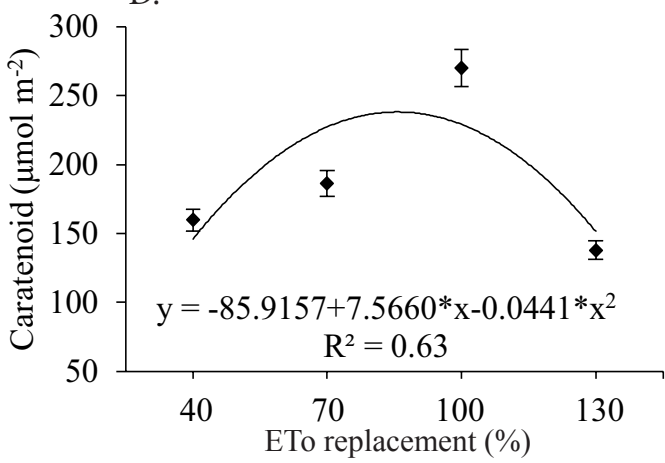

Figure 3. Contents of chlorophyll a (A), chlorophyll $b$ (B), total chlorophyll (C) and carotenoids (D) in sesame genotypes subjected to water replacement at 90 days after sowing

and $339.29 \mu \mathrm{mol} \mathrm{m}^{-2}$ ) were found at estimated water depths of $83.97,84.69$ and $78.30 \%$ ETo, respectively. Water replacement above these values caused reduction in chlorophyll contents, which reached values lower than those found with $40 \%$ ETo replacement.

Chlorophyll is one of the main factors related to plant photosynthetic efficiency and, consequently, to growth and adaptability to different environments and conditions caused by the various types of stress. Chlorophyll $b$, considered as accessory pigment, is a biochemical compound present in the chloroplasts that help light absorption. Its production is directly associated with chlorophyll $a$ production (Silva et al., 2002), and is more intense when plants are exposed to stress conditions. 
Therefore, the lower values found with water depth of $40 \%$ ETo may be an indication of absence of more severe stress on the plants, compared with the values found with $130 \%$ ETo replacement. Such behavior may indicate that sesame plants are more susceptible to the stress caused by excess of water than the one caused by its absence, corroborating the claim of Arriel et al. (2009), who point out that the crop, in general, is resistant to drought and suitable for cultivation in arid and semi-arid zones and in periods of scarce rainfall.

For the content of carotenoids, maximum estimated value $\left(238.60 \mu \mathrm{mol} \mathrm{m}^{-2}\right)$ was obtained with estimated water depth of $85.78 \%$ ETo (Figure 3D). Comparing the maximum content of carotenoids with the values found at water depths of 40 and $130 \%$ ETo, there was an increase of $63.23 \%$ as water depth varied from 40 to $85.78 \%$ ETo, followed by a reduction of $36.14 \%$ as water depth increased to $130 \%$ ETo.

Determining the content of carotenoids in plants subjected to some sort of stress is very important, due to their role in the dissipation of the energy intercepted. These pigments act as photoprotectors, deactivating singlet and triplet oxygen by absorbing the energy present in these compounds during their formation, which prevents oxidative damages to plant cells (Engel \& Poggiani, 1991; Taiz \& Zeiger, 2009; Brito et al., 2011; Rigon et al., 2012).

In this context, it can be inferred that plants with lower contents of this pigment would be more subject to damages caused by the excess of light to the photosystem. Nevertheless, reduction in carotenoids combined with low content of chlorophyll $a$ in the leaves of plants subjected to both absence and excess of water may contribute to increasing the injuries to the photosynthetic mechanism, leading to limitations in growth, development and production.

Plants protect their cells and subcellular compartments from cytotoxic effects caused by ROS by using antioxidant enzymes, such as catalase and peroxidase. In natural environment, antioxidative responses to abiotic variations are induced by similar mechanisms, which result in adaptations to drier or more humid periods, to days with higher or lower light incidence, as well as to high and low temperatures, since these factors lead to the increase in ROS contents and, consequently, stimulate likewise antioxidant activity (Sharma et al., 2012).

In the present study, water replacements below $80 \%$ and above $100 \%$ ETo reduced the antioxidant enzymatic activity. For catalase, lower activity was observed with the application of $40 \%$ ETo; however, the increment in water availability increased the activity of this enzyme until its maximum point $\left(10.11 \mu \mathrm{g} \mathrm{mL}^{-1}\right)$, estimated at the water depth corresponding to $87.47 \%$ ETo (Figure 4A). According to Sharma et al. (2012), occurrence of environmental stress may increase or decrease catalase activity, depending on the intensity, duration and type of stress.

Differently from what was observed, the lowest activity of peroxidase was observed with application of $130 \%$ ETo. Maximum estimated activity $\left(66.24 \mu \mathrm{g} \mathrm{mL}^{-1}\right)$ for peroxidase was found at estimated water depth of 79.24\% ETo (Figure $4 B)$. Such reduction in the activity of the enzymes in plants subjected to water stress conditions may be an indication of
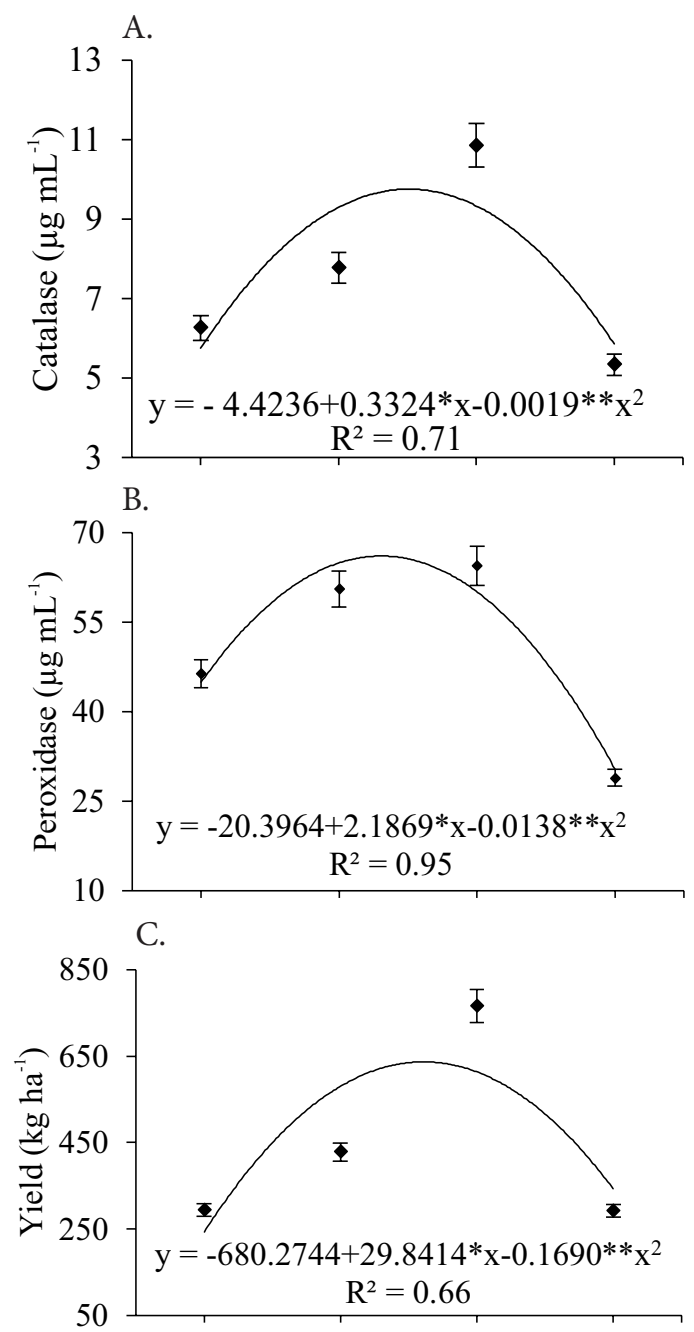

D.

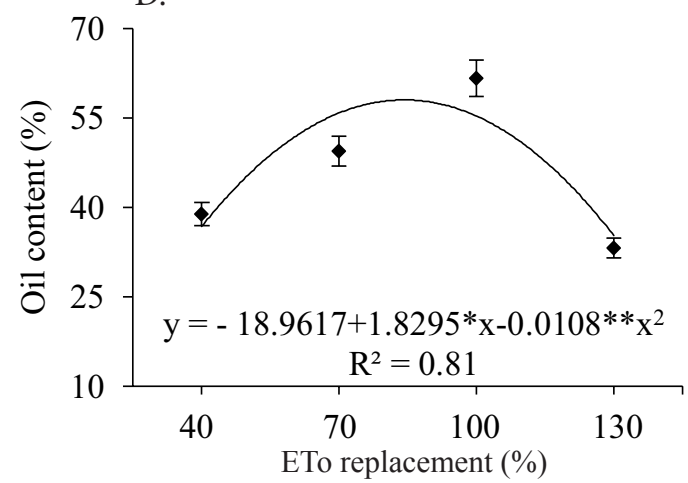

Figure 4. Antioxidant activity of catalase (A), peroxidase (B) at 50 days after sowing and grain yield (C) and oil content (D) in the seeds of sesame genotypes subjected to water replacement at 95 days after sowing

non-adaptation to the stressful environment, with effect on crop yield.

Regarding sesame yield (Figure 4C), the data fitted best to a quadratic polynomial model in the regression analysis, in which the application of $40 \%$ ETo led to the lowest mean yield estimated $\left(242.92 \mathrm{~kg} \mathrm{ha}^{-1}\right)$, even lower than the means of the world $\left(481.40 \mathrm{~kg} \mathrm{ha}^{-1}\right)$ and of the country $\left(600.00 \mathrm{~kg} \mathrm{ha}^{-1}\right)$, with plantations under rainfed conditions (Silva et al., 2002).

In contrast, from the water depth of $40 \%$ ETo on, there was a sharp increase in yield, reaching maximum of $637.19 \mathrm{~kg} \mathrm{ha}^{-1}$ when irrigated with estimated water depth of $88.29 \%$ ETo, and 
decreasing by $46.16 \%$ until the value of $343.01 \mathrm{~kg} \mathrm{ha}^{-1}$ with the application of $130 \%$ ETo. Maximum yields found with intermediate water depths may be directly associated with the improvements observed in physiological and biochemical processes, such as the water content in the leaves.

In addition, yield reduction is directly related to the water stress conditions, because plants use the stomatal closure mechanism to protect themselves from water losses through transpiration, leading to a reduction in the photosynthetic rate (Taiz \& Zeiger, 2009).

Oil content in the seeds increased with the increment in water replacement until the estimated water depth of $84.70 \%$ ETo, where maximum oil content was obtained (58.52\%), $36.94 \%$ higher than that found with application of the lowest irrigation depth (40\%) (Figure 4D). Nonetheless, increment in water depth above $84.70 \%$ caused mean reduction of $32.75 \%$ in the oil content of the seeds, reaching minimum value of $36.35 \%$.

It is known that sesame oil is rich in unsaturated fatty acids, such as oleic (47\%) and linoleic (41\%), and has various secondary constituents that are very important to define its chemical properties, such as sesamol, sesamin and sesamolin. Sesamol, with its antioxidant properties, promotes high chemical stability in the oil, preventing rancidification. Sesame oil has the highest resistance to oxidation among the other vegetable oils (Beltrão et al., 1994). In this context, sesame oil content becomes one of the most important variables to evaluate the feasibility of the crop from the agronomic point of view.

\section{Conclusions}

1. Sesame genotypes did not differ statistically and there were differences in the variables between the water replenishment rates. Increments in growth and, consequently, in production, enzymatic activity, oil content and maximum production potential were found with water depths between 75 and $90 \%$ ETo.

2. Contents of pigments, chlorophyll $a, b$, total and carotenoids, increased with the application of $80 \%$ ETo.

\section{ACKNOWLEDgments}

To the Coordination for the Improvement of Higher Education Personnel (CAPES) and the National Postdoctoral Program (PNPD) for granting the scholarships and financial support. To the Brazilian Agricultural Research Corporation (Embrapa Cotton) for providing the structure needed to conduct this study. In special, to Dr. Napoleão Esberard de Macêdo Beltrão (In memoriam) for his idealization and contributions during all the experiment.

\section{Literature Cited}

Arriel, N. H. C.; Firmino, P. T.; Beltrão, N. E. de M. Gergelim: O produtor pergunta, a Embrapa responde. Brasília, DF: Embrapa Informação Tecnológica, 2009. 209p.

Beltrão, N. E. de M.; Freire, E. C.; Lima, E. F. Gergelim cultura no trópico semiárido Nordestino. Campina Grande: EMBRAPA/ CNPA, 1994. 52p. Circular Técnica, 18
Bernardo, S.; Soares, A. A.; Mantovani, E. C. Manual de irrigação. 8.ed. Viçosa: UFV, 2009. 625p.

Bezerra, S. A.; Dantas Neto, J.; Azevedo, C. A. V. de; Silva, M. B. R.; Silva, M. M. da. Produção do gergelim cultivado sob condições de estresse hídrico e diferentes doses de adubação. Engenharia Ambiental, v.7, p.156-165, 2010.

Brito, G. G.; Brandão, Z. N.; Silva, V. B.; Franklin, M. S.; Silva, D. A. Non-destructive analysis of photosynthetic pigments in cotton plants. Acta Scientiarum. Agronomy, v.33, p.671-678, 2011. https://doi.org/10.4025/actasciagron.v33i4.10926

Carmo, C. A. F. de S.; Araújo, W. S. A. de; Bernardi, A. C. de C.; Saldanha, M. F. C. V. S. Métodos de análise de tecidos vegetais utilizados na Embrapa Solos. Rio de Janeiro: Embrapa Solos, 2000. 41p. Circular Técnica, 6

Dann, E. K.; Deverall, B. J. Activation of systemic disease resistance in pea by an avirulent bacterium or a benzothiadiazole, but not by a fungal leaf spot pathogen. Plant Pathology, v.49, p.324-332, 2000. https://doi.org/10.1046/j.1365-3059.2000.00457.x

Engel, V. L.; Poggiani, F. Estudo da concentração de clorofila nas folhas e seu espectro de absorção de luz em função do sombreamento em mudas de quatro espécies florestais nativas. Revista Brasileira de Fisiologia Vegetal, v.3, p.39-45, 1991.

Ferreira, D. F. Sisvar: Um programa para análise de ensino de estatística. Revista Científica Symposium, v.6, p.36-41, 2008.

Havir, E. A.; McHale, N. A. Biochemical and developmental characterization of multiple forms of Catalase in tobacco leaves. Plant Physiology, v.84, p.450-455, 1987. https://doi.org/10.1104/ pp.84.2.450

Hiscox, J. D.; Israelstam, G. F. A method for the extraction of chlorophyll from leaf tissue without maceration. Canadian Journal of Botany, v.57, p.1332-1334, 1979. https://doi.org/10.1139/b79-163

Mantovani, E. C.; Bernado, S.; Paloretti, L. F. Irrigação: Princípios e métodos. 6.ed. Viçosa: Imprensa Universitária, 2006. 625 p.

Mesquita, J. B. R. de; Azevedo, B. M. de; Campelo, A. R.; Fernandes, C. N. V.; Viana, T. V. de A. Crescimento e produtividade da cultura do gergelim (Sesamum indicum L.) sob diferentes níveis de irrigação. Irriga, v.18, p.364-375, 2013. https://doi.org/10.15809/ irriga.2013v18n2p364

Oxford Instruments. Oxford MQA 7000 Séries: Manual de operações. São Paulo: Oxford Instruments, 2007. 46p.

Pereira, R. A.; Villa Nova, N. A.; Sediyama, G. C. Evapotranspiração. Piracicaba: FEALQ, 1997. 183p.

Perin, A.; Cruvinel, J. D.; Silva, W. J. da. Desempenho do gergelim em função da adubação NPK e do nível de fertilidade do solo. Acta Scientiarum. Agronomy, v.32, p.93-98, 2010. https://doi. org/10.4025/actasciagron.v32i1.2521

Pinto, C. de M.; Távora, F. J. A. F.; Pinto, O. R. de O. Relações hídricas e trocas gasosas em amendoim, gergelim e mamona submetidas a ciclos de deficiência hídrica. Agropecuária Técnica, v.35, p.3440, 2014.

Rigon, J. P. G.; Beltrão N. E. de M.; Capuani S.; Brito Neto J. F.; Silva, F. V. F. Análise não destrutiva de pigmentos fotossintéticos em folhas de gergelim. Revista. Brasileira de Engenharia Agrícola e Ambiental, v.16, p.258-261, 2012. https://doi.org/10.1590/S141543662012000300004 
Sharma, P.; Jha, A. B.; Dubey, R. S.; Pessarakli, M. Reactive oxygen species, oxidative damage, and antioxidative defense mechanism in plants under stressful conditions. Journal of Botany, v.2012, p.1-26, 2012. https://doi.org/10.1155/2012/217037

Silva, J. C. A.; Fernandes P. D.; Bezerra, J. R. C.; Arriel, N. H. C.; Cardoso, G. D. Crescimento e produção de genótipos de gergelim em função de lâminas de irrigação. Revista Brasileira Engenharia Agrícola e Ambiental, v.18, p.408-416, 2014. https:// doi.org/10.1590/S1415-43662014000400008
Silva, L. C.; Santos, J. W. dos; Vieira, D. J.; Beltrão, N. E. de M.; Alves, I.; Jerônimo, J. F. Um método simples para se estimar a área foliar de plantas de gergelim (Sesamum indicum L.). Revista de Oleaginosas e Fibrosas, v.6, p.491-496, 2002.

Smart, R. E.; Bingham, G. E. Rapid estimates of relative water content. Plant Physiology, v.53, p.258-260, 1974. https://doi.org/10.1104/ pp.53.2.258

Taiz, L.; Zeiger, E. Fisiologia vegetal. 4.ed. Porto Alegre: Artmed, 2009, 848p. 